\title{
Pengaruh Kualitas Pelayanan terhadap Kepuasan Konsumen di Dapur Caringin Tilu Bandung
}

\author{
Helmi Ulul Azmi' ${ }^{1}$, Mochamad Whilky Rizkyanfi ${ }^{1}$, Ilham Fajri² \\ ${ }^{1}$ Universitas Pandidikan Indonesia, Manajemen Industri Katering, Jl. Dr. Setiabudhi No. \\ 229, Bandung 40154, Indonesia \\ ${ }^{2}$ Sekolah Tinggi Pariwisata Bandung, Perhotelan, Jl. Dr. Setiabudhi No. 186, Bandung \\ 40141, Indonesia
}

E-mail: helmiululazmi@upi.edu

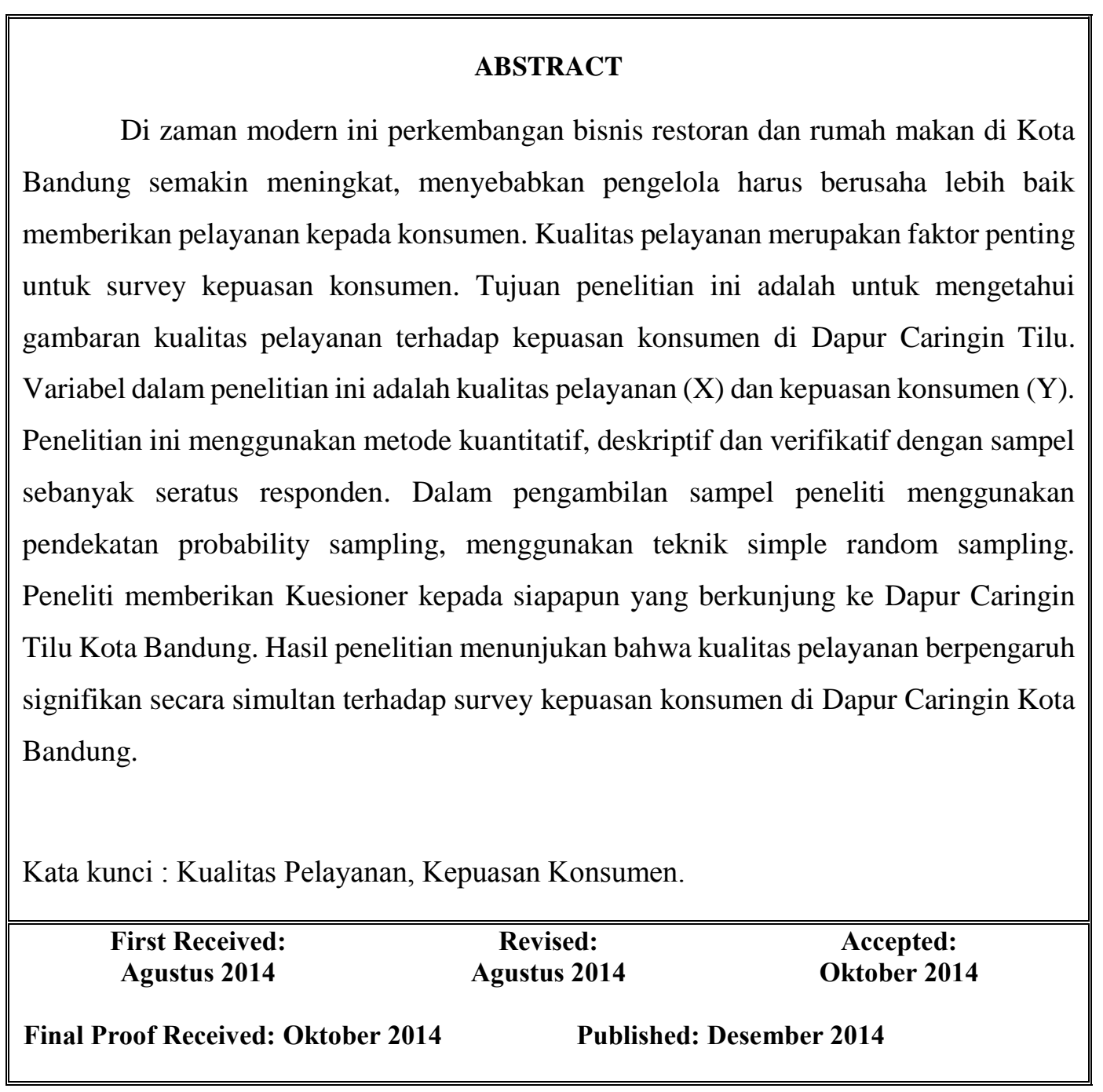




\section{Latar Belakang}

Berdasarkan UU No.10 Tahun 2009 yang berisi tentang kepariwisataan disebutkan bahwa pariwisata adalah berbagai kegiatan wisata dan didukung oleh masyarakat, pengusaha, pemerintah, serta pemerintah daerah. Daya tarik wisata adalah keanekaragaman kekayaan alam, budaya, dan hasil buatan manusia yang menjadi sasaran atau tujuan kunjungan wisatawan.

Industri pariwisata merupakan sebuah fenomena industri yang sedang berkembang untuk meningkatkan keadaan ekonomi sebagian besar negara di dunia. Namun, pembangunan kepariwisataan harus tetap memperhatikan jumlah penduduk. Jumlah penduduk akan menjadi satu di antara modal utama dalam pembangunan kepariwisataan pada masa sekarang dan yang akan datang karena memiliki fungsi ganda, selain sebagai aset sumber daya manusia, juga berfungsi sebagai sumber potensi wisatawan Nusantara.

Perkembangan pariwisata di Bandung saat ini tentunya sangat memberi dampak positif bagi perekonomian negara, bahkan termasuk beberapa daerah, sektor pariwisata merupakan jadi prioritas sumber pendapatan asli daerah.

Pemenuhan kebutuhan dan keinginan sangat ditentukan oleh tingkat kepentingan atau kepuasan pelanggan itu sendiri. Seiring makin banyaknya aktivitas di luar rumah yang sangat bervariasi oleh manusia, kesempatan orang yang bersifat cepat, praktis, dan nyaman makin tinggi. Menurut (Sumarwan, 2002), jumlah penduduk yang sangat besar membawa dampak penting bagi kehidupan masyarakat Indonesia. Satu di antara dampak penting adalah pemenuhan kebutuhan pangan yang sangat banyak untuk memenuhi konsumsi penduduk.

Ada beberapa jenis wisata yang ada di Kota Bandung, yaitu wisata alam, wisata religi, sejarah, wisata pendidikan, dan satu di antaranya yang akan dibahas peneliti, yaitu wisata kuliner. Wisata kuliner adalah satu di antara alternatif objek wisata yang digemari saat ini dan perkembangannya pun sangat cepat. Hal ini dapat terlihat dari berkembangnya industri kuliner di Kota Bandung.

Bisnis kuliner di Kota Bandung sangat menjanjikan, terlihat dari banyaknya restoran, café, rumah makan yang ada di Kabupaten dan Kota Bandung dengan berbagai konsep yang unik dan menarik yang menjadi tren saat ini. Hal ini bisa dilihat dari data berikut:

\begin{tabular}{|l|l|l|l|l|l|l|l|l|l|}
\hline \multirow{2}{*}{ Kota } & \multicolumn{3}{|c|}{ Restoran } & \multicolumn{3}{c|}{ Rumah Makan } & \multicolumn{3}{c|}{ Café } \\
\cline { 2 - 11 } & 2016 & 2017 & 2018 & 2016 & 2017 & 2018 & 2016 & 2017 & 2018 \\
\hline Bandung & 396 & 372 & 467 & 372 & 370 & 544 & 14 & 14 & 41 \\
\hline
\end{tabular}

Tabel 1. Jumlah Restoran, Rumah Makan, dan Cafe di Kota Bandung 2016-2018

Pada tabel 1. di atas yang dihimpun oleh Badan Pusat Statistik Jawa Barat dijelaskan bahwa untuk restoran sendiri di Kota Bandung mengalami penurunan dari tahun 2016 yang berjumlah 396 menjadi 372 di tahun 2017 dan mengalami kenaikan yang besar di tahun 2018 dengan jumlah 467 restoran. Rumah makan di tahun 2016 berjumlah 372 dan mengalami penurunan di tahun 2017 menjadi 370, seperti biasa di tahun 2018 selalu mengalami kenaikan yang cukup signifikan menjadi 544 rumah makan. Terakhir, cafe pada tahun 2016 yang berjumlah 14 masih sama dengan tahun selanjutnya tidak mengalami kenaikan ataupun penurunan, yaitu dengan jumlah 14, dan di tahun 2018 mengalami kenaikan menjadi 41 cafe.

Satu di antara restoran yang ikut bersaing di Kota Bandung adalah Dapur Caringin Tilu. Dapur Caringin Tilu merupakan rumah makan yang bertema foodcourt alam terbuka. Rumah makan yang terletak di Jalan Padasuka Atas Kampung Caringin 3 No.41, Cimenyan, Kec. Cimenyan, Kota Bandung, Jawa Barat 40197 berdiri sejak tahun 2006. Dalam perjalanannya yang kurang lebih sudah 15 tahun, rumah makan ini dihadapkan pada beberapa komplain mengenai pelayanan yang dirasa kurang oleh konsumen.

Tjiptono (2011) menyatakan kepuasan konsumen adalah "Kepuasan atau 
ketidakpuasan adalah respons konsumen terhadap evaluasi ketidaksesuaian/dikonfirmasi yang dirasakan antara harapan sebelumnya (atau norma kinerja lainnya) dan kinerja aktual produk yang dirasakan setelah pemakaiannya.

Kepuasan konsumen sangat berpengaruh dalam meningkatkan kinerja di Dapur Caringin Tilu, satu di antara cara yang dapat dilakukan oleh Dapur Caringin Tilu adalah meningkatkan kualitas pelayanannya. Menurut Goetsh dan Davis (dalam Tjiptono, 2002) dipaparkan bahwa kualitas pelayanan adalah suatu kondisi dinamis yang berhubungan dengan produk, jasa, manusia, proses, dan lingkungan yang memenuhi atau melebihi ekspektasi. Kualitas pelayanan yang baik akan memengaruhi kepuasan konsumen dan dapat dijadikan sebagai alasan berkunjung kembali.

\section{Kajian Pustaka}

\subsection{Pengertian Pariwisata}

Pariwisata adalah suatu perjalanan yang dilakukan orang untuk sementara waktu, yang diselenggarakan dari satu tempat ke tempat lain meninggalkan tempatnya semula, dengan suatu perencanaan dan dengan maksud bukan untuk berusaha atau mencari nafkah di tempat yang dikunjungi, tetapi semata-mata untuk menikmati kegiatan pertamasyaan dan rekreasi atau untuk memenuhi keinginan yang beraneka ragam (Sihite, 2000).

\subsection{Kualitas Pelayanan}

Parasuraman (Arief, 2007), kualitas pelayanan merupakan perbandingan antara layanan yang dirasakan sama atau melebihi kualitas layanan yang diharapkan sehingga layanan dapat dikatakan berkualitas dan memuaskan.

Menurut Parasuraman (Jasfar, 2005) terdapat lima dimensi kualitas pelayanan /jasa, di antaranya, sebagai berikut:

1. Realibility (keandalan)

Kemampuan untuk memberikan pelayanan yang dijanjikan dengan tepat (accurately) dan kemampuan untuk dipercaya (dependably), terutama memberikan jasa secara tepat waktu (on time), dengan cara yang sama sesuai dengan jadwal yang telah dijanjikan dan tanpa melakukan kesalahan tiap waktu.

2. Responsivisness (daya tanggap)

Kemauan atau keinginan para karyawan untuk membantu dan memberikan jasa yang dibutuhkan konsumen. Membiarkan konsumen menunggu, terutama tanpa alasan yang jelas, akan menimbulkan kesan negatif yang tidak seharusnya terjadi.

3. Assurance (jaminan)

Meliputi pengetahuan, kemampuan, ramah tamah, sopan, dan sifat dapat dipercaya dari kontak personel untuk menghilangkan keragu-raguan konsumen dan merasa terbebas dari bahaya dan risiko.

4. Empathy (empati)

Meliputi sikap kontak personel maupun perusahaan untuk memahami kebutuhan maupun kesulitan konsumen, komunikasi yang baik, perhatian pribadi, kemudahan dalam melakukan komunikasi atau hubungan.

5. Tangibles (produk-produk fisik)

Tersedianya fasilitas fisik, perlengkapan dan sarana komunikasi, dan lain-lain yang dapat diperluas dalam bentuk hubungan dengan konsumen lain pengguna jasa.

\subsection{Kepuasan Konsumen}

(Kotler \& Armstrong, 2012) menyatakan bahwa kepuasan adalah perasaan senang atau kecewa seseorang yang muncul setelah membandingkan kinerja (hasil) produk yang dipikirkan terhadap kinerja (hasil) yang diharapkan.

(Tjiptono, 2011) menyatakan kepuasan konsumen adalah kepuasan atau ketidakpuasan adalah respons konsumen terhadap evaluasi ketidaksesuaian/dikonfirmasi yang dirasakan antara harapan sebelumnya (atau norma kinerja lainnya) dan kinerja aktual 
produk yang dirasakan setelah pemakaiannya.

\subsection{Hipotesis}

Hipotesis hal yang penting dalam suatu penelitian (Sugiyono., 2012). Hipotesis merupakan jawaban sementara terhadap rumusan masalah penelitian.

Gambar 1. Model Hipotesis

Hipotesis juga dapat dinyatakan sebagai jawaban teoretis terhadap rumusan masalah penelitian sebelum jawaban empiris. Berdasarkan penelitian-penelitian

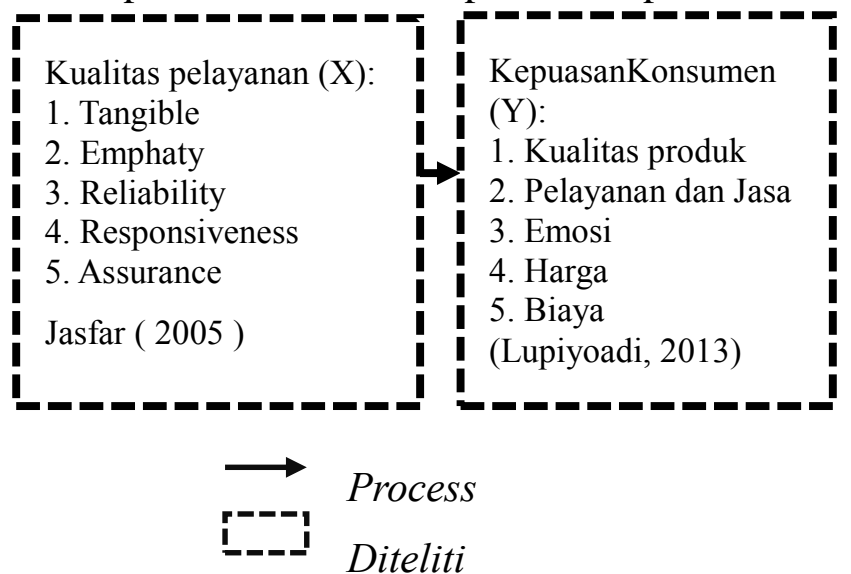

terdahulu dan rasionalisasi dari hubungan antarvariabel dalam penelitian ini, hipotesis yang diajukan dalam penelitian ini adalah sebagai kualitas pelayanan $(\mathrm{X})$ berpengaruh positif terhadap kepuasan konsumen (Y) Dapur Caringin Tilu.

\section{Metode Penelitian}

Penelitian ini dilakukan di restoran Dapur Caringin Tilu yang berada di Jalan Padasuka Atas No. 41, Bandung dan mulai beroperasi pada bulan Februari 2006. Penelitian ini menganalisis bagaimana pengaruh kualitas pelayanan terhadap kepuasan konsumen. Objek penelitian ini terdiri atas dua variabel, variabel bebas (independent variable) dan variabel terikat (denpendent variable). Adapun yang menjadi variabel bebas dalam penelitian ini yaitu kualitas pelayanan (X) sedangkan yang menjadi variabel terikat yaitu kepuasan konsumen (Y).

Penelitian ini dilakukan untuk mendeskripsikan tujuan penelitian dan menguji hubungan antara variabel dan menguji hipotesis. Oleh karena itu, jenis penelitian yang digunakan dalam penelitian ini adalah jenis penelitian kuantitatif dengan metode deskriptif dan verifikatif. (Sugiyono., 2013) mengemukakan bahwa "Penelitian deskriptif adalah penelitian yang dilakukan untuk mengetahui keberadaan variabel mandiri, baik satu variabel maupun lebih variabel (variabel yang berdiri sendiri) tanpa membuat perbandingan dan atau mencari hubungan variabel satu sama lain".

Menurut (Sugiyono., 2010) analisis kuantitatif merupakan metode penelitian kuantitatif dapat diartikan sebagai metode penelitian yang berlandaskan pada sample filsafat positivisme, digunakan untuk meneliti pada populasi atau sampel tertentu, pengumpulan data menggunakan instrument penelitian, analisis data bersifat statistik, dengan tujuan untuk menguji hipotesis yang telah ditetapkan. Sementara itu, penelitian verifikatif adalah penelitian yang dilakukan untuk menguji kebenaran suatu hipotesis melalui pengumpulan data di lapangan. Dengan menggunakan metode penelitian ini akan diketahui pengaruh yang signifikan antara variabel yang diteliti, sehingga menghasilkan simpulan yang akan memperjelas gambaran mengenai objek yang diteliti.

\subsection{Uji Validitas}

Adapun dalam penelitian ini yang akan diuji adalah validitas dari instrumen kualitas pelayanan yang terdiri dari aspek Tangible, Emphaty, Reliability, Responsiveness dan Assurance sebagai variabel $\mathrm{X}$ dan kepuasan konsumen sebagai variabel Y. Perhitungan validitas item instrumen dilakukan dengan menggunakan program SPSS Statistic 23 for windows. Berikut ini adalah hasil pengujian validitas dari item pertanyaan yang diajukan peneliti. Tabel 2. Hasil Uji Validitas

Syarat minimum untuk dianggap valid adalah $\mathrm{r}_{\text {hitung }}>\mathrm{r}$ table. Uji validitas instrumen dapat menggunakan rumus korelasi. Untuk mencari nilai korelasinya peneliti menggunakan rumus Pearson Product Moment (Product Moment Correlation Analysist), dengan menggunakan rumus konsep yang diajukan 
Sugiyono (2013) adalah sebagai berikut:

$$
=\frac{r_{x y}}{\sqrt{\left\{n \sum x_{1}^{2}-\left(\sum x_{1}\right)^{2}\right\}\left\{n \sum y_{1}{ }^{2}-\left(\sum y_{1}\right)^{2}\right\}}}
$$

Keterangan:

$r_{x y}=$ Koefisien korelasi pearson product moment

$\mathrm{n}=$ Banyaknya sampel

$\sum \mathrm{x}=$ Jumlah nilai variabel $\mathrm{x}$

$\sum \mathrm{y}=$ Jumlah nilai variabel $\mathrm{y}$

$\sum \mathrm{x}^{2}=$ Jumlah kuadrat variabel $\mathrm{x}$

$\sum \mathrm{y}^{2}=$ Jumlah kuadrat variabel $\mathrm{y}$

\begin{tabular}{|c|c|c|c|c|c|}
\hline No & Pertanyaan & $\mathbf{R}_{\text {hitung }}$ & $\mathbf{X}$ & $\mathbf{R}_{\text {tabel }}$ & Ket \\
\hline \multicolumn{6}{|c|}{ Kualitas Pelayanan } \\
\hline \multicolumn{6}{|c|}{ Tangibles (Bukti fisik) } \\
\hline 1. & $\begin{array}{l}\text { Tingkat kebersihan } \\
\text { ruangan restoran }\end{array}$ & 0.561 & $>$ & 0.361 & Valid \\
\hline 2. & $\begin{array}{l}\text { Tingkat kelengkapan } \\
\text { fasilitas yang ada di } \\
\text { restoran }\end{array}$ & 0.645 & $>$ & 0.361 & Valid \\
\hline 3. & $\begin{array}{l}\text { Kemudahan tempat } \\
\text { parkir }\end{array}$ & 0.614 & $>$ & 0.361 & Valid \\
\hline 4. & $\begin{array}{l}\text { Tingkat kerapian } \\
\text { pakaian karyawan }\end{array}$ & 0.568 & $>$ & 0.361 & Valid \\
\hline \multicolumn{6}{|c|}{ Reliability (Keandalan) } \\
\hline 5. & $\begin{array}{l}\text { Kecepatan karyawan } \\
\text { memberikan pelayanan }\end{array}$ & 0.528 & $>$ & 0.361 & Valid \\
\hline 6. & $\begin{array}{l}\text { Produk yang dibuat } \\
\text { sesuai dengan pesanan }\end{array}$ & 0.651 & $>$ & 0.361 & Valid \\
\hline 7. & $\begin{array}{l}\text { Nilai setruk sesuai } \\
\text { dengan pesanan yang } \\
\text { Anda pesan }\end{array}$ & 0.747 & $>$ & 0.361 & Valid \\
\hline 8. & $\begin{array}{l}\text { Kemampuan karyawan } \\
\text { berkomunikasi dengan } \\
\text { konsumen }\end{array}$ & 0.577 & $>$ & 0.361 & Valid \\
\hline 9. & $\begin{array}{l}\text { Kemampuan karyawan } \\
\text { menyajikan makanan } \\
\text { dengan baik }\end{array}$ & 0.404 & $>$ & 0.361 & Valid \\
\hline
\end{tabular}

Tabel 2. Hasil Validitas

\begin{tabular}{|c|c|c|c|c|c|}
\hline \multicolumn{6}{|c|}{ Responsiveness (Daya Tanggap) } \\
\hline 10. & $\begin{array}{l}\text { Kecepatan karyawan } \\
\text { menangani kebutuhan } \\
\text { konsumen }\end{array}$ & 0.533 & $>$ & 0.361 & Valid \\
\hline 11. & $\begin{array}{l}\text { Respons karyawan } \\
\text { terhadap keluhan } \\
\text { konsumen }\end{array}$ & 0.864 & $>$ & 0.361 & Valid \\
\hline 12. & $\begin{array}{l}\text { Karyawan membantu } \\
\text { konsumen yang ragu } \\
\text { terhadap pesanan }\end{array}$ & 0.717 & $>$ & 0.361 & Valid \\
\hline \multicolumn{6}{|c|}{ Assurance (Kepastian) } \\
\hline 13. & $\begin{array}{l}\text { Karyawan menguasai } \\
\text { tentang produk yang } \\
\text { dijual }\end{array}$ & 0.757 & $>$ & 0.361 & Valid \\
\hline 14. & $\begin{array}{l}\text { Kesopanan karyawan } \\
\text { terhadap pelanggan }\end{array}$ & 0.773 & $>$ & 0.361 & Valid \\
\hline 15. & $\begin{array}{l}\text { Konsumen merasa aman } \\
\text { saat melakukan proses } \\
\text { transaksi }\end{array}$ & 0.677 & $>$ & 0.361 & Valid \\
\hline \multicolumn{6}{|c|}{ Emphaty (Kepedulian) } \\
\hline 16. & $\begin{array}{l}\text { Kemudahan melakukan } \\
\text { pemesanan }\end{array}$ & 0.572 & $>$ & 0.361 & Valid \\
\hline 17. & $\begin{array}{l}\text { Kemudahan restoran } \\
\text { tersebut dalam } \\
\text { memberikan saran dan } \\
\text { keluhan }\end{array}$ & 0.580 & $>$ & 0.361 & Valid \\
\hline 18. & $\begin{array}{l}\text { Karyawan mampu } \\
\text { memahami dengan baik } \\
\text { keinginan konsumen }\end{array}$ & 0.513 & $>$ & 0.361 & Valid \\
\hline
\end{tabular}

Sumber: Data Diolah Penulis, 2021

Berdasarkan perhitungan Uji

Validitas dari tabel di atas, menunjukkan bahwa $r_{\text {hitung }}>r_{\text {tabel }}$ pada nilai signifikan $5 \%$ atau 0.361. Seluruh pertanyaan penelitian bernilai lebih besar dari $r_{\text {tabel, dapat }}$ disimpulkan bahwa semua pertanyaan pada kuesioner di atas dinyatakan valid sehingga dapat digunakan sebagai instrumen penelitian.

\subsection{Uji Reliabilitas}

Reliabilitas (keandalan) merupakan ukuran konsistensi responden dalam menjawab pertanyaan yang merupakan dimensi dari variabel yang disusun dalam kuesioner. Reliabilitas adalah sejauh mana hasil pengukuran dengan menggunakan objek yang sama akan menghasilkan data yang sama (Sugiyono., 2013).

Uji reliabilitas dalam penelitian ini, peneliti menggunakan metode Alpha Cronbach. Alpha cronbach adalah rumus matematis yang digunakan untuk menguji tingkat reliabilitas ukuran. Cornbach Alpha (a) dengan menggunakan software IBM 
SPSS Statisticts versi 25.0 for windows. Suatu instrumen dikatakan reliabel jika nilai cornbach's alpha lebih besar dari 0,5 yang dirumuskan adalah sebagai berikut:

Keterangan:

$$
A=\frac{k \cdot r}{1+(k-1) \cdot r}
$$

$\mathrm{A}=$ Koefisien reliabilitas

$\mathrm{k}=$ Jumlah item reliabilitas

$\mathrm{r}=$ Rata-rata korelasi antar item

$1=$ Bilangan konstanta

Tabel 3. Hasil Realibilitas

\begin{tabular}{|c|c|c|c|}
\hline Variabel & $\mathbf{r}_{\mathbf{x y}}$ & $\mathbf{r}_{\text {tabel }} \mathbf{5 \%}$ & Keterangan \\
\hline $\mathrm{X}-$ & 0.908 & 0.361 & Realiabel \\
\hline $\mathrm{Y}$ & 0.927 & 0.361 & Realiabel \\
\hline
\end{tabular}

Hasil uji realibiltas diperoleh nilai koefisien angket $\mathrm{X}$ sebesar 0.908 dan nilai koefisien angket $\mathrm{Y}$ sebesar 0.927 . Berdasarkan hasil angket tersebut, dapat disimpulkan hasil pada angket adalah realiabel atau koefisien sehingga instrumen pada angket peneliti dapat digunakan sebagai instrumen penelitian.

\section{Pembahasan dan Hasil}

Berdasarkan hasil temuan penelitian menunjukan bahwa kualitas pelayanan secara parsial memperoleh nilai signifikansi $0,000<0,05$ dan $t_{\text {hitung }} 9.781>\mathrm{t}_{\text {tabel }} 1.984$ artinya secara parsial ada pengaruh yang signifikan dan positif antara kualitas pelayanan dengan kepuasan konsumen. Kualitas pelayanan yang terdiri dari dimensi dan wujud (tangible), keandalan (reliability), daya tanggap (responsiveness), kepastian (assurance), dan empati (emphaty) yang memperoleh total skor sebesar 1.943,1 dari skor ideal atau maksimal. Indikator dengan perolehan skor rata rata tertinggi yaitu kepastian (assurance) dengan perolehan rata rata skor 407 , dikarenakan karyawan menguasai prosuk yang dijual, karyawan bersikap sopan dan konsumen merasa aman saat melakukan transaksi. Perolehan skor dari responden terhadap kualitas pelayanan terletak pada interval 6.460-7.980 atau pada daerah kontinum kategori tinggi. Kemudian hasil penelitian menunjukan bahwa kepuasan konsumen dipengaruhi oleh kualitas pelayanan secara positif dan signifikan, dengan nilai korelasi sebesar 0,703 yang berarti adanya tingkat hubungan yang kuat antar variabel. Kemudian nilai koefisien determinasi $\left(\mathrm{R}^{2}\right)$ sebesar 0.494 menunjukkan bahwa setiap dimensi Kualitas Pelayanan (X) berkontribusi sebesar $49,4 \%$ dalam meningkatkan Kepuasan Konsumen (Y). Sedangkan sisanya yaitu sebesar $50.6 \%$ merupakan faktor-faktor yang tidak diteliti dalam penelitian ini.

Variabel kepuasan konsumen yang terdiri dari harapan kualitas produk, ketetapan pelayanan, emosi, harga dan biaya memperoleh total skor dari responden sebesar 2,015 atau 51\% dari skor ideal atau maksimal, hasil tersebut menunjukan bahwa tingkat harapan kepuasan konsumen termasuk dalam kategori tinggi karena terletak pada interval 1.700 sampai 2.100 yang merupakan daerah kontinum tinggi. Sedangkan kenyataan dari kualitas produk, ketetapan pelayanan, emosi, harga dan biaya memperoleh skor dari responden sebesar 1,834 atau $49 \%$ dari skor ideal, hasil tersebut menunjukan bahwa tingkat kenyataan kepuasan konsumen termasuk dalam kategori tinggi karena terletak pada interval 1.700 sampai 2.100 yang merupakan daerah kontinum tinggi.

Tabel 4. Hasil Analier Regresi Sederhana

\begin{tabular}{|c|c|c|c|c|c|c|c|}
\hline \multicolumn{8}{|c|}{ Coefficients $^{a}$} \\
\hline \multirow{2}{*}{ Model } & \multicolumn{2}{|c|}{$\begin{array}{c}\text { Unstandardized } \\
\text { Coefficients }\end{array}$} & \multirow{2}{*}{\begin{tabular}{|c|c|}
$\begin{array}{c}\text { Standardiz } \\
\text { ed } \\
\text { Coefficien }\end{array}$ \\
Beta
\end{tabular}} & \multirow{2}{*}{$\mathrm{T}$} & \multirow{2}{*}{ Sig. } & \multicolumn{2}{|c|}{ Collinearity Statistics } \\
\hline & B & Std. Error & & & & Tolerance & VIF \\
\hline (Constant) & 5.465 & 3.581 & & 1.526 & .130 & & \\
\hline $1 \begin{array}{l}\text { Kualitas } \\
\text { Pelayanan }\end{array}$ & .476 & .049 & .703 & 9.781 & .000 & 1.000 & 1.000 \\
\hline
\end{tabular}

a. Dependent Variable: Kepuasan Konsumen

Sumber :Data Hasil Pengolahan (2021)

Persamaan Umun Regresi Linear sederhana adalah :

$$
\mathrm{Y}=\mathrm{a}+\mathrm{bx}
$$

Setelah nilai a dan b ditentukan, maka persamaan regresi linear sederhana dapat disusun. Persamaan nilai modal kerja dan 
perputaran persediaan seperti berikut :

$$
Y=5,465+0.476 X
$$

Dari persamaan diatas dapat dilihat pengaruh yang terjadi antara kualitas pelayanan $(\mathrm{X})$ dan kepuasan konsumen $(\mathrm{Y})$ tersebut dapat dijelaskan sebagai berikut :

1. Konstanta sebesar 5,465 artinya jika kualitas pelayanan $(\mathrm{X})$ nilainya adalah nol, maka kepuasan konsumen (Y) adalah 0,476 .

2. Angka koefisien regresi nilainya sebesar 0,476 , yang berarti setiap penambahan $1 \%$ tingkat kualitas pelayanan (X), maka kepuasan konsumen (Y) sebesar 0.476. Karena nilai koefsien regresi bernilai positif maka dapat dikatakan bahwa kualitas pelayanan (X) berpengaruh posotif terhadap kepuasan konsumen (Y).

\section{Tabel 5. Hasil Uji Koefisien Determinasi}

\begin{tabular}{|c|c|c|c|c|}
\hline \multicolumn{5}{|c|}{ Model Summaryb } \\
\hline $\begin{array}{l}\text { Mod } \\
\text { el }\end{array}$ & $\mathrm{R}$ & $\begin{array}{c}\mathrm{R} \\
\text { Square }\end{array}$ & $\begin{array}{l}\text { Adjusted } \\
\text { R Square }\end{array}$ & $\begin{array}{c}\text { Std. } \\
\text { Error of } \\
\text { the } \\
\text { Estimate }\end{array}$ \\
\hline & $.703^{a}$ & .494 & .489 & 3.07152 \\
\hline
\end{tabular}

a. Predictors: (Constant), Kualitas Pelayanan

b. Dependent Variable: Kepuasan Konsumen Sumber:Data Hasil Pengolahan (2021)

Berdasarkan perhitungan tersebut diketahui besarnya kualitas pelayanan (X) terhadap kepuasan konsumen (Y) ditunjukan dengan besar nilai koefisien $\mathrm{R}$ Square sebesar 0,494 merupakan nilai koefisien determinasi yang berasal dari pengkuadratan nilai koefisien $\mathrm{R}$ sebesar 0.703 .

Dari tabel diatas dapat disimpulkan bahwa pengaruh kualitas pelayanan sebesar 0.494 atau $49,4 \%$ terhadap kepuasan konsumen yang dimana sisanya $50.6 \%$ merupakan faktor lain yang tidak diteliti oleh penulis.

Uji t digunakan untuk menguji secara parsial masing-masing variabel. Uji $t$ dimulai dengan penetapan hipotesis nol dan hipotesis alternative, penelitian uji statistik dan perhitungan uji statistik, perhitungan hipotesis, penetapan tingakat signifikan dan penarikan kesimpulan. Hipotesis yang akan digunakan dalam penelitian ini berkaitan dengan ada atau tidaknya pengaruh variabel $\mathrm{X}$ terhadap variabel $\mathrm{Y}$.

\begin{tabular}{|c|c|c|c|c|c|c|c|}
\hline \multicolumn{8}{|c|}{ Coefficients $^{\mathrm{a}}$} \\
\hline \multirow[t]{2}{*}{ Model } & \multicolumn{2}{|c|}{$\begin{array}{l}\text { Unstandardized } \\
\text { Coefficients }\end{array}$} & \multirow{2}{*}{\begin{tabular}{|c|}
$\begin{array}{c}\text { Standardiz } \\
\text { ed } \\
\text { Coefficien }\end{array}$ \\
Beta \\
\end{tabular}} & \multirow[t]{2}{*}{$\mathrm{T}$} & \multirow[t]{2}{*}{ Sig. } & \multicolumn{2}{|c|}{ Collinearity Statistics } \\
\hline & B & Std. Error & & & & Tolerance & $\mathrm{VIF}$ \\
\hline (Constant) & 5.465 & 3.581 & & 1.526 & .130 & & \\
\hline 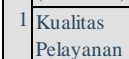 & .476 & .049 & .703 & 9.781 & .000 & 1.000 & 1.000 \\
\hline
\end{tabular}

Tabel 6. Hasil Uji Parsial

Sumber:Data Hasil Pengolahan (2021)

Berdasarkan perhitungan tersebut dapat di ketahui bahwa nilai thitung $9.781>$ $\mathrm{t}_{\text {tabel }} 1.984$ sehingga $\mathrm{Ho}$ ditolak dan $\mathrm{H}_{1}$ diterima, artinya secara parsial ada pengaruh signifikan antara Kualitas Pelayanan dengan Kepuasan Konsumen. Jadi, dapat disimpulkan bahwa secara parsial Kualitas Pelayanan berpengaruh positif terhadap Kepuasan Konsumen di Dapur Caringin Tilu Bandung.

Berdasarkan hasil tersebut maka penulis memperkuat temuan penelitian dari (Ulandari, 2019) yang menyatakan bahwa seluruh variabel secara sama-sama (simultan) berpengaruh terhadap tingkat kepuasan konsumen rumah makan ikan bakar di kelurahan komo luar manado. Untuk mencapai tujuan bisnis anda, ciptakanlah kepuasan konsumen agar hubungan menjadi harmonis dan tujuan bisnis anda tercapai (Umar, 2003) Hal ini menunjukan jika kualitas pelayanan ditingkatkan maka kepuasan konsumen juga akan meningkat.

Hasil temuan penulis memperkuat temuan penelitian (Tyas Kurniawati, Bambang Irawan, 2019) yang menyatakan bahwa kualitas layanan berpengaruh terhadap kepuasan konsumen serta sesuai dengan harapan, maka dari itu semakin tinggi kualitas pelayanan maka kepuasan konsumen semakin meningkat. (Goetsch, 
David L. \& Davis, 1994) mendefinisikan kualitas pelayanan merupakan suatu kondisi dinamis yang berhubungan dengan produk jasa, manusia, proses dan lingkungan yang mampu memenuhi dan atau melebihi harapan konsumen.

\section{Kesimpulan dan Saran}

\subsection{Kesimpulan}

Berdasarkan penelitian yang telah dilakukan untuk mengatahui hasil uji validitas dan reliabilitas, dengan menggunakan regresi sederhana antara kualitas pelayanan terhadap kepuasan konsumen di Dapur Caringin Tilu Bandung, maka dari penelitian tersebut dapat diambil kesimpulan sebagai berikut:

1. Dari hasil kuisioner, membuktikan bahwa kualitas pelayanan di Dapur Caringin Tilu Bandung masuk dalam kategori tinggi dengan besaran $77,79 \%$ dari. Hal tersebut menunjukan kualitas pelayanan mendapatkan perhatian yang tinggi dari kepuasan konsumen.

2. Dari hasil kuisioner, kepuasan konsumen terdiri dari harapan dan kenyataan, dapat diketahui bahwa harapan kepuasan konsumen masuk dalam kategori sangat tinggi dengan besaran $80,6 \%$, sedangkan kenyataan dari kepuasan konsumen masuk dalam kategori tinggi dengan besaran $73,36 \%$. Artinya konsumen berharap kepuasan konsumen sesuai dengan harapan mereka, tetapi kenyataan kepuasan konsumen yang diberikan, berada dibawah harapan nya.

3. Kualitas Pelayanan memiliki pengaruh positif yang signifikan terhadap kepuasan konsumen. Hal ini terbukti dengan besaran yang artinya ada pengaruh yang signifikan dan positif antara kualitas pelayanan dengan kepuasan konsumen.

\subsection{Saran}

Dalam penelitian yang dilakukan di Dapur Caringin Tilu Bandung, penulis mengalami keterbatasan dikarenakan ada penademi Covid-19 sehingga tempat makan di kota bandung tidak beroperasi, maka dari itu penulis memanfaatkan sosial media untuk menyebarkan kuisioner, maka saran yang dapat diberikan adalah sebagai berikut:

1. Penilaian terhadap kualitas pelayanan dengan penilaian terendah adalah indikator dari wujud (tangible) Dapur Caringin Tilu Bandung, dikarenakan masih kurangnya tingkat kebersihan dan fasilitas yang kurang dan kurangnya kerapihan pakaian karyawan contohnya alat makan yang kurang di meja makan, meja yang masih lengket, lantai yang masih kotor, pegawai yang seragam dan penampilan nya tidak rapih. Maka dari itu, saran yang di berikan untuk pihak Dapur Caringin Tilu yaitu kembali memperhatikan tingkat kebersihan yang ada, dan kelengkapan fasilitas, serta diberi SOP terhadap pakaian atau penampilan karyawan.

2. Berdasarkan hasil penelitian, penulis melihat bahwa kualitas pelayanan berpengaruh signifikan terhadap kepuasan konsumen, artinya jika kualitas pelayanan ditingkatkan maka kepuasan juga akan meningkat. Maka diharapkan pihak Dapur Caringin Tilu Bandung agar memperhatikan hasil temuan penelitian ini dengan menjadikan faktor-faktor yang mempengaruhi kepuasan konsumen sebagai strategi manajemen pemasaran untuk meningkatkan daya tarik pembeli.

Penilaian terhadap kepuasan konsumen dengan penilaian terendah yaitu dari kenyataan kepuasan konsumen indikator tingkat ketepatan kualitas pelayanan. Maka diharapkan pihak Dapur Caringin Tilu Bandung lebih memperhatikan faktor-faktor ketetapan pelayanan agar pelayanan yang diberikan sesuai dengan harapan para konsumen. 


\section{Daftar Pustaka}

Arief. (2007). Pemasaran Jasa \& Kualitas Pelayanan. Bayumedia Publishing, Malang.

Goetsch, David L. \& Davis, S. M. (1994). Introduction to Total Quality: Quality, Productivity, Competitiveness

(Merrill's international series in engineering technology). Prentice Hall International Inc.

Jasfar, F. (2005). Manajemen Jasa Pendekatan Terpadu. Bogor: Ghalia Indonesia.

Kotler, P., \& Armstrong, G. (2012). Marketing Management (14th ed.). New Jersey: Pearson Prentice Hall.

Sihite, R. (2000). Tourism Industry (Kepariwisataan). Surabaya: Penerbit SIC.

Sugiyono. (2010). Statistika Untuk Penelitian. Bandung: Alfabeta.

Sugiyono. (2012). Metode Penelitian Pendidikan. Bandung: Alfabeta.

Sugiyono. (2013). Metode Penelitian
Pendidikan (Pendekatan Kuantitatif, Kualitatif, dan R\&D). Bandung: Alfabeta.

Sumarwan, U. (2002). Perilaku Konsumen. Ghalia Indonesia.

Tjiptono. (2002). Manajemen Jasa. Yogyakarta: ANDI.

Tjiptono, F. (2011). Prinsip-Prinsip Total Quality Service. Yogyakarta: Andi.

Tyas Kurniawati, Bambang Irawan, A. P. (2019). Analisis Pengaruh Kualitas Pelayanan, Harga, dan Brand Image Terhadap Kepuasan Konsumen Restoran Pizza Hut Cabang Jember. Jurnal Manajemen, Universitas Jember, 5(1).

Ulandari, V. A. R. J. I. S. (2019). Pengaruh Pelayanan Rumah Makan Ikan Bakar Terhadap Kepuasan Konsumen Di Kelurahan Komo Luar Manado. Jurnal Bisnis Universitas Sam Ratulangi, 7(no.3).

Umar. (2003). Riset Pemasaran Dan Perilaku Konsumen. Gramedia Pustaka Utama. 